\title{
HUBUNGAN ANTARA PENGUASAAN KOSAKATA DENGAN KETERAMPILAN BERBICARA BAHASA JERMAN SISWA KELAS XI BAHASA SMA NEGERI 2 KABUPATEN MAJENE
}

\author{
Desi Nuraina $^{1}$ dan Nurming Saleh ${ }^{2}$ \\ Fakultas Bahasa dan Sastra, Universitas Negeri Makassar \\ E-mail ${ }^{1}$ : desinuraina@gmail.com
}

\begin{abstract}
ABSTRAK
Penelitian ini bertujuan untuk mengetahui Hubungan antara Penguasaan Kosakata Bahasa Jerman dengan Keterampilan Berbicara Siswa Kelas XI Bahasa SMA Negeri 2 Kabupaten Majene. Pengumpulan data pada penelitian ini dilakukan tes kosakata dan tes keterampilan berbicara dan menganalisis Data digunakan Product Moment. Populasi penelitian ini adalah siswa kelas XI Bahasa yang berjumlah 18 orang. Data yang diperoleh melalui teknik Total Sampling. Hasil analisis data menjelaskan bahwa $\mathrm{Rh}=(0,543)>\mathrm{Rt}=(0,468)$. Hasil penelitian menunjukkan bahwa ada hubungan yang signifikan antara penguasaan kosakata bahasa Jerman dengan keterampilan berbicara siswa kelas XI Bahasa SMA Negeri 2 Kabupaten Majene $(\mathrm{rh}=0,543>\mathrm{rt}=0,468)$.
\end{abstract}

\section{Kata Kunci: Kosakata, Keterampilan Berbicara, Bahasa Jerman}

\begin{abstract}
This study aims to determine the relationship between the German language vocabulary with speaking skills English class XI SMA Negeri 2 Majene. Collecting data in this study conducted with the written and oral tests and analyzed by product moment correlation. The study population was a class XI student language totaling 19 people. The study population selected through total sampling technique. The results of data analysis explain that $\mathrm{rh}=(0.754)>\mathrm{rt}=(0.456)$. The results showed that no significant relationship between the German language vocabulary skills of English speaking class XI student of SMAN 2 Majene $(\mathrm{rh}=0.754>\mathrm{rt}=0.456)$.
\end{abstract}

\section{Keywords: Vocabulary, Speaking Skills, German Language}

\section{PENDAHULUAN}

Bahasa Jerman sebagai bahasa asing diajarkan di Sekolah Menengah Atas (SMA), Sekolah Menengah Kejuruan (SMK) dan Madrasah Aliah (MA) sebagai kompetensi yang terdapat dalam pembelajaran bahasa berdasarkan yang telah di lakukan terhadap siswa. Siswa diarahkan untuk terampil menggunakan bahasa tersebut dalam berinteraksi baik secara langsung maupun tidak langsung dengan orang di sekitarnya. Ada empat kompetensi yang diajarkan dalam pembelajaran bahasa Jerman, yaitu kemampuan menyimak (Hören), kemampuan membaca (Lesen), keterampilan berbicara (Sprechen), keterampilan menulis (Schreiben). Selain keempat aspek tersebut juga ditunjang oleh dua aspek, yakni kemampuan tata bahasa (Strukturen) dan kosakata(Wortschatz).Semua kompetensi tersebut saling berhubungan satu dengan yang lain.

Kosakata merupakan suatu elemen penting dalam mempelajari bahasa Jerman 
yang sangat berpengaruh dalam keterampilan berbicara. Penguasaan kosakata yang rendah membuat mereka kesulitan dalam keterampilan berbicara (Mantasiah, 2007). Oleh karena itu diperlukan penguasaan kosakata. Menurut Vina (2014:57) Tingkat jumlah kosakata untuk bahasa Jerman seperti yang tertulis dalam standar kompetensi, kompetensi dasar, indikator, dan Materi Pokok Mata Pelajaran Bahasa Jerman yaitu untuk kelas X semester 1 menguasai kuarang lebih 250 kosakata (aktif 150 kosakata), semester 2 menguasai kurang lebih 550 kosakata (aktif 350 kosakata), Kelas XI semester 1 menguasai 800 kosakata (aktif 550 kosakata), Semester 2 menguasai kurang lebih 1000 kosakata (aktif 700 kosakata).

Berdasarkan pengamatan yang telah dilakukan terhadap siswa kelas Bahasa SMA Negeri 2 Majene yang belajar bahasa Jerman, ditemukan bahwa siswa mengalami kesulitan menyampaikan informasi secara lisan dngan lafal yang tepat dalam berbicara bahasa Jerman, diduga karena kurangnya penguasaan kosakata bahasa Jerman.

Hal tersebut di atas didukung oleh hasil penelitian yang telah dilakukan oleh Yoan Ardillah (2014) yang mengatakan bahwa keterampilan berbicara bahasa Jerman siswa rendah $(23,4 \%)$. Sedang hasil penelitian yang dilakukan oleh Ari Sri Wahyuni (2012) menyimpulkan bahwa penguasaan kosakata siswa termasuk dalam kategori cukup dengan nilai 69,05. Kemudian didukung hasil penelitian yang telah dilakukan oleh Yuliatun menyatakan bahwa terdapat hubungan positif yang signifikan antara penguasaan kosakata dengan keterampilan berbicara dengan nilai koefisien korelasi sebesar rh 0,8. Hal inilah yang mendorong peneliti untuk menghubungkan antara penguasaan kosakata dengan keterampilan berbicara bahasa Jerman.

\section{KOSAKATA}

Kosakata adalah salah satu aspek kemampuan yang berperan penting dalam penguasaan bahasa seseorang. Tarigan (1986) mengatakan bahwa bahasa merupakan katakata yang kita kenal saat mempelajari bahasa. Semakin kaya kosakata yang dimiliki maka semakin besar pula kemungkinan kita untuk terampil berbahasa.

Tarigan (1986: 23) mengemukakan, "pembelajaran kosakata bertujuan untuk: (1) meningkatkan taraf kehidupan siswa, yaitu kemampuan siswa dalam menyerap ilmu bahasa lebih tinggi, (2) meningkatkan taraf kemampuan mental siswa, yaitu siswa yang mengungkapkan pendapatnya di depan umum, (3) meningkatkan taraf perkembangan konseptual, artinya bersifat imajinatif dan tidak membandingkan dari satu sisi saja, (4) mempertajam proses berfikir siswa secara kritis, artinya siswa dapat menyelesaikan permasalahan secara komperhensif, (5) memperluas cakrawala pandangan hidup siswa, artinya sudut pandang pemahaman siswa tidak sempit. Kualitas keterampilan berbahasa seseorang jelas bergantung kepada kuantitas dan kualitas kosakata yang dimilikinya (Tarigan, 1986: 2) kosakata merupakan katakata yang kita kenal saat mempelajari bahasa. Semakin kaya kosakata yang dimiliki maka semakin besar pula kemungkinan kita untuk terampil berbahasa."

$$
\text { Kemudian Keraf }
$$
merumuskan "pengertian kosakata, yakni keseluruhan kata yang dimiliki suatu bahasa. Kosakata tidak lain adalah daftar kata yang segera akan diketahui artinya bila didengarkan kembali walaupun jarang ataupun tidak pernah digunakan lagi dalam percakapan atau tulisan kita sendiri."

Berdasarkan beberapa pendapat di atas dapat disimpulkan bahwa, kosakata adalah perbendaharaan kata serta himpunan kata dalam suatu kata dan bahasa. Tanpa kosakata orang tidak akan dapat berkomunikasi baik secara lisan ataupun tulisan.

Kosakata merupakan faktor kebahasaan yang sangat esensial yang harus dikuasai oleh peserta didik supaya dapat 
berbahasa Jerman dengan baik dan benar. Kuantitas dan kualitas kosakata seseorang turut menentukan kualitas dan bobot kemampuan mentalnya. Oleh sebab itu penguasaan kosakata dasar bahasa Jerman harus dikuasai peserta didik. Nurgiyantoro (2010: 166) menyebutkan bahwa kosakata merupakan alat utama yang harus dimiliki seseorang yang akan belajar bahasa, untuk membentuk kalimat serta mengutarakan isi pikiran dan perasaan baik secara lisan maupun tertulis. Berdasarkan beberapa pendapat disimpulkan bahwa kosakata merupakan faktor kebahasaan yang sangat esensial yang merupakan bagian dari penguasaan bahasa dalam yang harus dikuasai oleh peserta didik supaya dapat berbahasa Jerman dengan baik dan benar.

\section{KEMAMPUAN BERBICARA}

Berbicara merupakan alat komunikasi tatap muka yang sangat vital. Menurut Nurgiyantoro (2010: 399) mengatakan berbicara merupakan aktivitas berbahasa kedua yang dilakukan manusia dalam kehidupan bahasa setelah mendengarkan. Berdasarkan bunyi-bunyi (bahasa) yang didengar kemudian manusia belajar mengucapkan dan pada akhirnya mampu untuk berbicara. Djiwandono (2011: 118) mengatakan bahwa berbicara berarti mengungkapkan pikiran secara lisan. Dengan mengutarakan apa yang dipikirkan seseorang dapat membuat orang lain yang diajak bicara mengerti apa yang ada dalam pikirannya. Pengertian lain dari berbicara diungkapkan oleh Humboldt (Dalam Steinig dan Huneka, 2011: 56) yang mengatakan "Das Sprechen ist Ausdruck des Gedanken oder der Empfindung" yang artinya berbicara adalah ungkapan dari pikiran atau perasaan.

Berdasarkan pengertian di atas dapat disimpulkan bahwa berbicara merupakan aktivitas berbahasa kedua yang dilakukan manusia dalam kehidupan bahasa setelah mendengarkan. Berbicara berarti mengungkapkan gagasan pikiran antara penyimak dan pembicara dengan kemampuan artikulasi untuk menyatakan serta mengutarakan apa yang dipikirkan dan perasaan seseorang baik bertatap muka langsung maupun tidak langsung.

Keterampilan merupakan kemampuan yang disertai dengan kemahiran melakukan sesuatu dan untuk memilikinya diperlukan latihan yang teratur. Keterampilan berbahasa yang harus dimiliki oleh seluruh peserta didik di sekolah meliputi empat aspek dasar, yaitu kemampuan menyimak (Hörverstehen), kemampuan membaca (Leseverstehen), keterampilan menulis (Schreibfertigkeit), dan keterampilan berbicara (Sprechfertigkeit)

Menurut Tarigan (2013:1) setiap keterampilan itu berhubungan erat pula dengan proses-proses berfikir yang mendasari bahasa. Bahasa seseorang mencerminkan pikirannya. Kemudian Zainurahman (2011:2) berpendapat bahwa "keterampilan bahasa dibagi menjadi dua jenis, yaitu keterampilan yang biasa diperoleh secara alami dan keterampilan yang hanya diperoleh melalui latihan-latihan dan penguasaan konsep tertentu.

Definisi lain dikemukakan oleh Nurjamal (2014:23) "Berbicara sebagai suatu keterampilan, hanya akan dimiliki dikuasai seseorang apabila dia mau berlatih". Berdasarkan pengertian di atas disimpulkan bahwa kegiatan- keterampilan berbicara itu merupakan keterampilan berikutnya yang kita kuasai setelah kita menjalani proses latihan belajar menyimak, keterampilan terdiri atas keterampilan yang diperoleh secara alami dan dari latihan-latihan, serta untuk menguasai keterampilan berbicara harus terus berlatih. Berbicara itu merupakan kemampuan seseorang untuk mengungkapkan gagasan-pikiranperasaan secara lisan kepada orang lain. Pembelajaran keterampilan berbicara harus mampu memberikan kesempatan kepada setiap individu untuk mencapai tujuan yang dicitacitakan. 
Berbicara memberikan peranan sosial dan merupakan alat komunikasi yang penting dalam kehidupan manusia. Tujuan keterampilan berbicara menurut Iskandarwassid dan Sunendar (2008: 286) dapat dirumuskan sebagai berikut. "(1) Peserta didik dapat melafalkan bunyi bahasa, (2) menyampaikan informasi, (3) menyatakan setuju atau tidak setuju, (4) menjelaskan identitas diri, (5) menceritakan kembali hasil simakan atau bacaan, (6) menyatakan ungkapan rasa hormat, (7) bermain peran."

Tarigan (2013:16) mengungkapkan tujuan utama dari berbicara adalah untuk berkomunikasi. Agar dapat menyampaikan pikiran secara efektif, seyogianyalah sang pembicara memahami makna segala sesuatu yang ingin dikomunikasikan. Menurut Wahyuni dan Ibrahim (2012:131) tujuan utama keterampilan berbicara adalah untuk berkomunikasi agar dapat menyampaikan pikirannya secara efektif, maka si pembicara harus memahami makna segala sesuatu yang ingin dikomunikasikan. Dia harus mengevaluasi efek komunikasinya terhadap pendengar dan dia harus mengetahui prinsip-prinsip yang mendasari segala situasi pembicara baik secara umum maupun perorangan. Berdasarkan beberapa pendapat diatas maka dapat ditarik kesimpulan bahwa tujuan berbicara adalah menyampaikan informasi untuk berkomunikasi serta mengetahui makna yang dikomunikasikan secara efektif agar si pembicara memahami makna segala sesuatu yang ingin dikomunikasikan.

\section{METODE PENELITIAN}

Pada penelitian ini, digunakan dua variabel yaitu penguasaan kosakata bahasa Jerman siswa sebagai variabel bebas (X) dan keterampilan berbicara bahasa Jerman sebagai variabel terikat (Y). Penelitian ini merupakan penelitian korelasional yang bertujuan untuk mengetahui hubungan antara penguasaan kosakata bahasa Jerman dengan keterampilan berbicara siswa kelas XI Bahasa SMA Negeri 2 Majene.

Penguasaan kosakata yang dimaksud dalam penelitian ini adalah penguasaan kosakata siswa yang meliputi: 1) Kata benda, 2) Kata kerja, 3) Kata sifat dan 4) Kata penghubung. Keterampilan berbicara yang dimaksud dalam penelitian ini adalah kemampuan siswa menyampaikan informasi dalam bahasa Jerman secara lisan dengan lafal yang tepat.

Populasi dalam penelitian ini adalah seluruh siswa kelas XI Bahasa SMA Negeri 2 Majene yang terdiri atas satu kelas yang berjumlah siswa 18 orang. Sampel penelitian ini adalah keseluruhan siswa kelas XI Bahasa SMA Negeri 2 Majene dengan jumlah siswa sebanyak 18 (sampel total).

Data dalam penelitian ini diperoleh melalui dua tes, yaitu tes kosakata das tes keterampilan berbicara bahasa Jerman. Tes penguasaan kosakata siswa yang berrbentuk tes objektif sebanyak 50 butir soal, dan untuk tes keterampilan berbicara bahasa Jerman dalam bentuk tes lisan terdiri dari 5 soal yang berkaitan dengan tema die Familie. Pengumpulan data dalam tes keterampilan berbicara diperoleh dengan merekam. Bentuk tes objektif sebanyak 50 soal yang terdiri atas:Penguasaan kata benda, Penguasaan kata kerja, Penguasaan kata sifat, Penguasaan kata penghubung

\section{HASIL DAN PEMBAHASAN}

Penelitian ini, terdiri dari dua variabel yaitu penguasaan kosakata sebagai variabel bebas (variabel $\mathrm{X}$ ) dengan keterampilan berbicara sebagai variabel terikat (variabel Y). Adapun penjelasan dari kedua data tersebut dapat digambarkan sebagai berikut: 


\section{Hasil Analisis Data Tes Penguasaan Kosakata}

Berdasarkan perhitungan maka ditemukan 6 kelas interval. Rentang data sebesar $72-30=42$. Dari rentang data yang diperoleh maka panjang kelas intervalnya adalah $42 / 6=(7)$, Berdasarkan pada tabel menunjukkan bahwa dari 18 sampel diperoleh 1 siswa $(5,5 \%)$ yang skornya berada pada kelas interval 30-36, 2 siswa (11\%) yang skornya berada pada kelas interval 37-43, 3 siswa $(16,5 \%)$ yang skornya berada pada kelas interval 44-50, 6 siswa (33 \%) yang skornya berada pada kelas interval 51-57, 5 siswa (27\%) yang berada pada kelas interval 58-64, 3 siswa $(16,5)$ yang berada pada kelas interval 65-72. Ini artinya bahwa terdapat 1 kelas interval yang memiliki frekuensi tertinggi yaitu 51-57 dengan frekuensi 6 siswa $(33, \%)$.

\section{Hasil Analisis Tes Keterampilan berbicara}

Data yang diperoleh dari penelitian untuk variabel keterampilan berbicara, skor terendah yang dicapai siswa adalah 3 dan skor tertinggi yang dicapai siswa adalah 8 .

Adapun jumlah rentang data tentang nilai yang diperoleh siswa dalam tes keterampilan berbicara bahasa Jerman, dengan menggunakan nilai konversi penilaian sekolah diperoleh kelas Interval dengan melihat jumlah rentang data $66,66-25=41,66$ dan banyak kelas interval yaitu 41,66/6=6,83 (7).

Berdasarkan pada data menunjukkan bahwa dari 18 sampel diperoleh 1 siswa $(5,5 \%)$ yang skornya berada pada kelas interval 24,531,3 siswa $(16,5 \%)$ yang skornya berada pada kelas interval 38,5-45, 3 siswa $(16,5 \%)$ yang skornya berada pada kelas interval 45,5-52, 4 siswa $(22 \%)$ yang skornya berada pada kelas interval 52,5-59, 1 siswa $(5,5 \%)$ yang skornya berada pada kelas interval 59,5. Ini artinya bahwa ada1 kelas interval yang memiliki frekuensi tertinggi yaitu pada interval 24,5-31 dengan frekuensi 7 siswa $(38,8 \%)$.

Penelitian ini terdiri atas dua tes yaitu tes penguasaan kosakata bahasa Jerman dan tes keterampilan berbicara bahasa Jerman. Dari kedua hasil tes tersebut kemudian dianalisis dengan menggunakan rumus Product Moment

Data dari hasil penelitian tes penguasaan kosakata, tes obyektif sebanyak 50 nomor nilai maksimal 100. Dari tes tersebut maka diperoleh nilai terendah yaitu 30 dan nilai tertinggi yang dicapai siswa adalah 72 . Berdasarkan hasil analisis data dapat diketahui bahwa nilai rata-rata yang diperoleh siswa dalam tes ini adalah $\mathbf{5 5 , 3 3}$ mendapatkan nilai yang kurang atau termasuk dalam kategori rendah

Hasil penelitian tes keterampilan berbicara bahasa Jerman dengan berupa tes lisan yang bertema die Familie memiliki nilai maksimal 100. Dari tes tersebut, maka diperoleh nilai terendah yang dicapai siswa adalah 25 dan nilai tertinggi yang dicapai siswa adalah 66,66. Adapun nilai rata-rata siswa adalah 41,66 pada kategori penilaian nilai 41,66 termasuk dalam kategori nilai yang kurang sekali atau kategori rendah

Nilai yang diperoleh siswa pada tes penguasaan kosakata dan keterampilan berbicara dianalisis dengan menggunakan teknik korelasi Product Moment, dari hasil perhitungan diperoleh hasil bahwa $\mathrm{R}$ hitung lebih besar daripada $\mathrm{R}$ tabel $(0,543>0,468)$. Dengan demikian dapat disimpulkan bahwa terdapat korelasi yang signifikan antara penguasaan kosakata dengan keterampilan berbicara bahasa Jerman.

Dari hasil analisis data yang diperoleh dari kedua tes penguasaan kosakata bahasa Jerman dan keterampilan berbicara kemudian dikategorikan dalam penilaian (purwanto:2009) untuk penguasaan kosakata termasuk dalam kategori kurang dan untuk keterampilan berbicara termasuk dalam kategori kurang sekali.

Dari kedua tes tersebut yaitu tes penguasaan kosakata serta tes keterampilan berbicara masing-masing nilai yang diperoleh siswa termasuk dalam kategori kurang yang menunjukan bahwa penguasaan kosakata merupakan faktor yang berkontribusi pada nilai 
keterampilan berbicara siswa yang juga termasuk dalam kategori kurang.

Penguasaan kosakata bahasa Jerman merupakan salah satu faktor yang penting terhadap keterampilan berbicara. Dalam proses berbicara, siswa dilatih untuk berbicara lisan bahasa Jerman dengan baik. Namun siswa memiliki kendala dalam berbicara. Hal ini disebabkan minimmya penguasaan kosakata yang membuat mereka sulit menyusun kalimat.

Siswa yang penguasaan kosakatanya rendah mengakibatkan keterampilan berbicara bahasa Jerman rendah, karena mereka memiliki penguasaaan kosakata yang sangat terbatas. Siswa yang mempunyai kosakata yang memadai dapat menentukan kualitas keterampilan berbahasanya. Semakin banyak kosakata yang dimiliki seseorang, semakin terampil pula dalam berbahasa, dalam hal ini adalah keterampilan berbicara.

Berdasarkan beberapa penjelasan di atas maka dapat disimpulkan bahwa penguasaan kosakata merupakan faktor yang berkotribusi dalam keterampilan berbicara bahasa Jerman. Dengan demikian siswa yang tidak memiliki pengusaan kosakata yang baik akan kesulitan dalam berbicara bahasa Jerman. Semakin banyak kosakata yang dimiliki siswa, semakin baik pula keterampilan berbicara siswa.

\section{KESIMPULAN}

Berdasarkan analisis data yang telah dipaparkan, maka dapat disimpulkan bahwa penguasaan kosakata bahasa Jerman siswa adalah berada pada kategori sedang dengan nilai rata-rata 55,33. Keterampilan berbicara bahasa Jerman siswa adalah berada pada kategori kurang sekali dengan rata-rata nilai rata 41,66 dan koefisien korelasi Penguasaan Kosakata dengan Keterampilan Berbicara sebesar R hitung $0.543>\mathrm{R}$ tabel 0,468 yang termasuk dalam kategori sedang. Artinya bahwa terdapat hubungan positif yang signifikan antara penguasaan kosakata bahasa Jerman dengan keterampilan berbicara.

\section{DAFTAR PUSTAKA}

Abidin, Yunus. 2012. Pembelajaran Bahasa Berbasis Pendidikan Karakter. Bandung: PT. Refika Aditama.

Arikunto, Suharsimi. 2010. Dasar-dasar Evaluasi Pendidikan. Jakarta: Bumi Aksara

Akhaidah, Sabarti. 1988. Evaluasi dalam Pengajaran Bahasa. Jakarta: Depdikbud

Amalputra,L.Y.H. 1994. Pengaruh Teknik Penerjemahan terhadap Hasil Belajar Mahasiswa Ditinjau dari Aspek Kemampuan Verbal. Jakarta: Program Studi Pendidikan Bahasa Jerman, FBS UNY.

Apriyaningsih, Vina. 2014. Keefektifan Penggunaan Media Pembelajaran Kartu Domino Dalam Pembelajaran Kosakata Bahasa Jerman Peserta Didik Kelas XI SMA Negeri 2 Yogyakarta. Skripsi S1. Yogyakarta: Program Studi Pendidikan Bahasa.

Ardiansyah. 2014. Keterampilan Berbicara Bahasa Jerman Siswa Kelas XI IPA SMA Negeri 9 Makassar. Skripsi S1. Makassar. Program Studi Pendidikan Bahasa.

Ardilla, Yoan. 2014. Keefektifan Penggunaan Media Time Token Dalam Pembelajaran Keterampilan Berbicara Bahasa Jerman Peserta Didik Kelas X SMA Negeri 1 Sedayu Bantul. Skripsi S1. Yogyakarta. Program Studi Pendidikan Bahasa.

Bolton, Silbylle. 1995. Problem der Leistung. München. Goethe Institut Langendscheidt.

Cahyo, Ungki Dwi. 2014. Penerapan Media Puzzle Picture Pada Kemampuan Berbicara Siswa Kelas XI IPA 2 SMA Negeri 1 Tumpang. Malang : Jurnal Penelitian. 
Djiwandono, Soenardi. 2008. Tes Bahasa Pegangan bagi Pengajar Bahasa. Jakarta: PT. Indeks.

Götz, Dieter dan Hans Wellman. 2009. Langenscheidt Power Wörterbuch Deutsch. Berlin: Langendscheidt.

Götz, Dieter. 1997. Langenscheidts Grö $\beta$ wörterbuch Deutsch ala Fremdsprache. Berlin dan Münschen: Langenscheidts.

Hardjono, Tini. 2009. Kontakte Deutsch 2. Jakarta : Katalis

Haryadi, Moh. 2009. Statistik Pendidikan. Banyuwangi: Prestasi Pustaka Raya.

Hidayat. 2014. Upaya Peningkatan Kemampuan Berbicara dengan Penerapan Pendekatan Komunikatif pada Pembelajaran Bahasa. Skripsi S1.Jakarta. Universitas Pendidikan Indonesia.

Hornby, A.S.1974. Oxford Advanced Learner's Dictionary of Current Englisch. Oxford: Oxford Universiry Press.

Irhana. 2015. Hubungan antara Penguasaan Kosakata dengan Keterampilan Menulis Surat Pribadi Bahasa Jerman Siswa Kelas XI Bahasa SMA Negeri 1 Bontonompo Kabupaten Gowa. Skripsi pada Jurusan Pendidikan Bahasa Jerman UNM: tidak diterbitkan.

Iskandarwassid dan Sunendar, D. 2008. Strategi Pembelajaran Bahasa. Bandung: PT. Remaja Rosda Karya.

Kasim. 2013. Deutsch ist Einfach. Solo : PT Tiga Serangkai Pustaka Mandiri.

Keraf, Gorys. 1996. Diksi dan Gaya Bahasa. Jakarta: Gramedia Pustaka Utama. Kridalakasana, Harimurti. 2008. Kamus Linguistik. Jakarta : PT Gramedia Pustaka Utama.

Mantasiah, R. 2007. Sintaksis bahasa Kodeoha: suatu kajian transformasi generatif (Doctoral dissertation, Universitas Hasanuddin).
Mukidi, Adisumarto.1984: Bahasa Baik dan Benar merupakan Ciri Utama Seorang Pendidik Jogjakarta: IKIP FPBS.

Nurgiyantoro, Burhan. 2001. Penilaian dalam Pengajaran Bahasa dan Sastra. Yogyakarta: Jakarta: BPFE.

Nurgiyantoro, Burhan. 2010. Penilaian dalam Pengajaran Bahasa. Jakarta: Gramedia

Nurjamal, Daeng, dkk.2014. Terampil Berbahasa. Bandung: Alfabeta.

Purwanto. Evaluasi Hasil Belajar. Yogyakarta:Pustaka Belajar 2009

Soedjito. 1992. Kosakata Bahasa Indonesia. Jakarta: PT Gramedia Pustaka Utama.

Sri Whyuni, Ari. 2012. Peningkatan Peenguasaan Kosakata Melalui Media Teks Teka Teki Silang Siswa Kelas XI IA 1 SMA Kartika Wirabuana 1 Makassar. Skripsi S1. Makassar. Program Studi Bahasa Jerman. Universitas Negeri Makassar. Tidak diterbitkan.

Steinig, Wolfgang dan Huneke Hans-Werner. 2011. Sprachdidaktik Deutsch. Berlin. Erich Schmidt Verlag.

Sugiyono. 2015. Metode Penelitian Pendidikan. Bandung: Alfabeta.

Tarigan, H.G.2011. Pengajaran kosakata. Bandung: Angkasa.

Tarigan,H.G. 2008. Berbicara Sebagai Suatu Keterampilan. Bandung: Angkasa

Wahyuni dan Ibrahim. 2012. Asesmen Pembelajaran Bahasa. Bandung: Refika ADITAMA.

Yuliatun. 2009.Hubungan Penguasaan Kosakata dengan Keterampilan Berbicara Siswa Kelas VI Sekolah Dasar Negeri 2 Bulusulur di Kecamatan Wonogirib Kecamatan Wonogiri Kabupaten Wonogiri. Skripsi S1. Surakarta. Universitas Sebelas Maret. 